This is a self-archived - parallel published version of this article in the publication archive of the University of Vaasa. It might differ from the original.

\title{
Why and how to compete through sustainability : a review and outline of trends influencing firm and network-level transformation
}

Author(s): Parida, Vinit; Wincent, Joakim

Title: Why and how to compete through sustainability : a review and outline of trends influencing firm and network-level transformation

Year: $\quad 2019$

Version: Publisher's PDF

Copyright (C)2019 the author(s), Springer Nature. This article is distributed under the terms of the Creative Commons Attribution 4.0 International $\quad(\mathrm{CC} \quad \mathrm{BY}) \quad$ License, http://creativecommons.org/licenses/by/4.o/, which permits unrestricted use, distribution, and reproduction in any medium, provided you give appropriate credit to the original author(s) and the source, provide a link to the Creative Commons license, and indicate if changes were made.

\section{Please cite the original version:}

Parida, V., \& Wincent, J., (2019). Why and how to compete through sustainability : a review and outline of trends influencing firm and network-level transformation. International entrepreneurship and management journal 15, 1-19. https://doi.org/10.1007/s11365-019-00558-9 


\title{
Why and how to compete through sustainability: a review and outline of trends influencing firm and network-level transformation
}

\author{
Vinit Parida ${ }^{1,2} \cdot$ Joakim Wincent ${ }^{1,3,4}$
}

Published online: 16 January 2019

(C) The Author(s) 2019

\begin{abstract}
This article reviews and discusses how to compete with sustainability by reviewing the literature about sustainability, business models, innovation, and networks. It is an introduction to the special issue on "innovative inter-organizational networks and sustainable economy: current trends and future opportunities" and a call for more research where we examine and outline ideas for how the new and rapidly spreading trends of digitalization, the circular economy, and servitization are force firms to develop new types of competitive advantages. We elaborate upon the transformation needs at firm-level capabilities and business models, as well as network-level changes through the formation of new ecosystems and new ways of engaging in co-creation with partners. These firm and network level transformation discussions are complimented with specific list potential areas for future academic research.
\end{abstract}

Keywords Review · Definition · Sustainability · Digitalization, servitization, circular economy, business models, sustainable innovation $\cdot$ Networks $\cdot$ Ecosystems

\section{Introduction}

The impact of sustainability, resource scarcity, and environmental deterioration and the need to manage new types of responsibilities in a changing world are important topics

Joakim Wincent

joakim.wincent@hanken.fi

Vinit Parida

vinit.parida@ltu.se

1 Department of Business Administration, Technology and Social Sciences, Luleå University of Technology, Lulea, Sweden

2 Department of Management, University of Vaasa, Vaasa, Finland

3 Entrepreneurship and Management, Hanken School of Economics, Helsinki, Finland

4 University of St.Gallen, Dufourstrasse 40a, St., CH-9000 Gallen, Switzerland 
in academia and industry practice (Elkington 1997). An emerging body of research spanning different literatures espouses the argument that sustainability, broadly defined as the management of balanced and responsible production to ensure enduring and long-lasting corporate relationships, living conditions, and social conditions, will change the business landscape by placing new demands on the skills and abilities of a company's resource base. Arguments and results presented in related research suggest that changes in a company's current and future way of working are crucial to the development and execution of strategies and business development plans to secure a source of competitive advantage. Although largely in its emerging stages, this research shows that the attention of management is important to help create a source of competitive advantage that stems from the exploitation of sustainable opportunities (Lahti et al. 2018). According to Reim et al. (2015), sustainability can ensure the achievement of economic, social, and environmental goals as companies simultaneously improve resource use and competitiveness. For example, manufacturing companies increasingly take a product life-cycle view. This view enables them to generate economic value through service standards, reduce environmental effects through longer product lifespans, and benefit society by eliminating low-value-adding jobs. Thus, the forum for the debate on sustainability has moved from environmental management journals to entrepreneurship and strategic management journals, where the issues of sustainability, innovation, and competitiveness are central (Cohen and Winn 2007; Dean and McMullen 2007; Schaltegger 2002). For scholars and, perhaps especially, practitioners such as managers, entrepreneurs, and corporate leaders, the emergence of certain transformational trends forces them to rethink and reorganize business operations to make sustainability an organizational priority. The focus on sustainability is nothing new, but in the light of new trends, the timing for companies to undertake this significant transformation could not be better. Based on analysis of diverse literature, we identify three trends that move from linear to circular thinking (Lewandowski 2016; Roome and Louche 2016), from a product-centric to service-centric approach (Lenka et al. 2018b; Parida et al. 2015; Tuli et al. 2007), and from an analogue to a digital focus (Brynjolfsson and McAfee 2014; Lenka et al. 2017). Respectively, these trends are captured by the concepts of the circular economy, servitization, and digitalization. Studies increasingly recognize these perspectives as individual and collective drivers of internal and external changes for companies to achieve sustainability-based competitive advantages (Frishammar et al. 2018). However, scarce research and empirical study has explored how these underlying trends drive the sustainability orientation of companies, how company innovation and entrepreneurship activities align with these trends, and how companies may need to rethink the way they develop the next generation of networks and ecosystems to align with the next generation of corporate innovation.

The identified trends are highly influential because they introduce new approaches, contingencies, and actions that are central for firm- and network-level transformation. Based on a review of the literature and contributions to the IEMJ special issue on sustainability, innovation, and networks, we outline how research has discussed firmlevel transformation in terms of new business models (Mont 2002; Reim et al. 2015), capability development (Parida et al. 2015; Ulaga and Reinartz 2011), network-level transformation in ecosystem orchestration (Tukker 2015), and co-creation with partners (Sjödin et al. 2016). For example, servitization combined with digitalization creates 
new requirements for companies and their network to move away from productoriented business models toward result- or digitally enabled outcome-oriented business models (Reim et al. 2015). Moreover, companies and their service network partners must develop digitalization capabilities to ensure that they can co-create value with customers (Lenka et al. 2017; Sjödin et al. 2016). Figure 1 builds on this logic, illustrating a framework of the way trends influence how firms and networks are built for competition in today's economy, where sustainability is a key outcome for companies and entrepreneurs. Figure 1 also depicts how companies are forced to follow these trends and how companies can develop competitive advantages that work toward sustainable benefits. In this special issue introduction, we review articles in the aforementioned area and discuss the influence of a set of prominent trends and organizational and network transformational needs. The aim is to provide a set of relevant research themes to be addressed by the sustainability, innovation, and network literature.

\section{Emerging trends influencing sustainability}

Companies must meet new demands to remain competitive, differentiating themselves from competitors by generating higher economic, environmental, and social value. We argue that the emerging trends of the circular economy, servitization, and digitalization drive this transformation. Circular economy suggests the need for a system-level view of resources and their value generation potential (MacArthur et al. 2015). This may entail firms and partners shouldering life-cycle responsibilities, shifting from unrenewable to renewable energy, embracing recycling, reuse, refurbishing, and remanufacturing of products, and improving maintenance commitments (Tukker 2014). Servitization refers to transformation toward a service-dominant logic (Vargo and Lusch 2008), which stresses the importance of providing solutions rather than products (Kohtamäki et al. 2013; Lenka et al. 2018a). Finally, digitalization represents the growing focus on sensors, connectivity, and analytics, which when combined, can

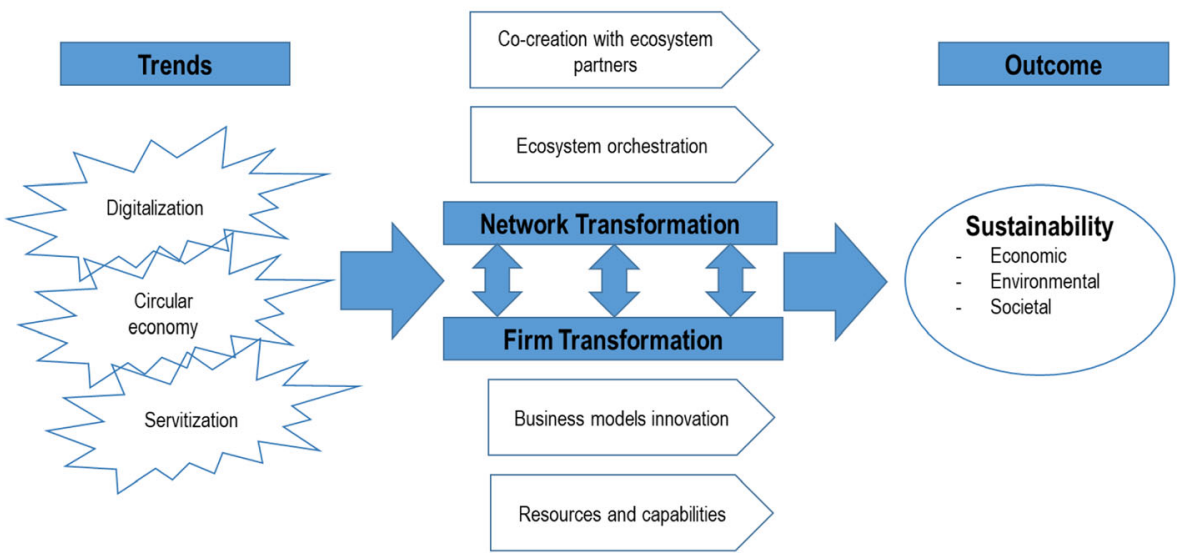

Fig. 1 Framework for emerging trends, transformation, and sustainability outcomes 
offer novel business and revenue generation opportunities (Porter and Heppelmann 2014).

In the following subsections, we discuss the implications of these trends on companies and their network actors. These new transformational requirements that build on the three aforementioned trends are influential in establishing a new research agenda.

\section{Circular economy (trend 1)}

Over the past century, business success was essentially equated to generating financial returns for shareholders (Upward and Jones 2016). This dominant focus on economic performance has contributed to numerous well-publicized environmental problems, where excessive use of limited resources has caused pollution, climate change, global warming, and ozone layer depletion. Many would argue that extensive economically driven business activities are a cause of such environmental problems (Schaltegger et al. 2016). However, companies increasingly place sustainability issues atop the corporate agenda, a sign that being a leader entails meting economic and environmental goals (Nußholz 2017; Lewandowski 2016).

Indeed, many companies and managers now deliberately combine products and services to help the environment and improve profitability at the same time (Kibler et al. 2018; Upward and Jones 2016). In recent years, such environmental initiatives have frequently been labeled as managing demands to transfer toward a circular economy. The term circular economy was first defined by the Ellen Macarthur foundation as "an industrial system that is restorative or regenerative by intention and design" (MacArthur et al. 2015). This approach relies on three guiding principles: preserving and enhancing natural capital, optimizing resource yield, and fostering system effectiveness. Many incumbent firms apply these guiding principles by adopting a cradle-to-cradle logic whereby firms consider life-cycle responsibilities, shift from unrenewable to renewable energy, embrace recycling, reuse, refurbishing, and remanufacturing of their products, and improve maintenance commitments (Frishammar and Parida 2018). However, the circular economy calls for a transformation in traditional ways of doing business, which can prove challenging.

According to Kortmann and Piller (2016), two motives drive companies to engage in activities aimed at advancing toward the circular economy. Whereas some may have identified a promising business opportunity, others may have been forced to do so by increasingly demanding legal regulations. In both cases, companies must rethink and reconfigure their existing business logic, which may involve a radical transformation. However, adapting to the circular economy can be done in many ways. Recent studies argue that new types of doing business are critical to successfully realize the activities inherent to the circular economy (Lewandowski 2016; Roome and Louche 2016).

The ReSOLVE (regenerate, share, optimize, loop, virtualize, and exchange) framework provides numerous ways in which incumbent firms generate higher value for customers while creating economic and environmental benefits by addressing circular economy concerns (MacArthur et al. 2015). For example, an incumbent firm's value proposition must change as it shifts toward increasingly sophisticated outcome-based contracts (Reim et al. 2015). Similarly, there may be significant changes to the firm's value capture mechanisms, such as when revenues from selling material-intensive upfront products are replaced with monthly earnings from providing product availability 
in the form of, say, a pay-per-use model (Tukker 2004). Thus, all three dimensions of companies' value creation, delivery, and capture are shifted toward solutions rather than a standalone product or service, which involves reevaluating relationships with new and former ecosystem actors. The fundamentals of business logic thereby shift toward a circular business model logic (Storbacka et al. 2013). Despite its relevance, the literature lacks insights into circular business model transformation and the way to change existing businesses in practice.

\section{Servitization (trend 2)}

Companies across various industries increasingly offer industrial services (Gebauer et al. 2005). This transition toward "servicification" (Normann 2001) or "servitization" (Vandermerwe and Rada 1988) by traditional manufacturing companies shifts their logic from goods dominant to service dominant (Vargo and Lusch 2008). Many would argue that servitization is increasingly normal in today's changing environment. Not only does post-sales involvement provide an additional source of revenue, but it also allows producers to develop more integrated designs that move beyond arms-length transactions (Tukker 2015; Kohtamäki et al. 2013). However, repositioning traditional products as advanced services entails significant challenges for companies.

Recent studies have proposed numerous reasons for examining why manufacturing companies are unable to offer industrial services successfully. For example, companies seem to be caught in a situation in which, for instance, certain necessary components and capabilities are missing (Ulaga and Reinartz 2011), service business models are immature (Meier et al. 2010), internal processes are misaligned (Lightfoot and Gebauer 2011), and service delivery networks are undeveloped (Baines et al. 2009). Companies may also find it demanding to increase fidelity in relationships with customers because they must also invest in developing knowledge exchange routines to enhance service avenues in the post-purchase phase (Ulaga and Reinartz 2011). All of these reasons imply that servitization represents a significant transformation for companies and network partners.

The transition to offering industrial services may be extreme when fully implemented or when a competitor implements the model to outcompete other companies in an industry. Industrial services include bundles of products and/or services that meet customers' specific needs, especially when the producer seeks to meet more futurespecific needs by taking full responsibility throughout a product's life cycle. This is one of the more advanced services companies can offer. Such responsibility offers greater potential for value creation than the potential offered by the individual components alone (Davies et al. 2006; Reim et al. 2016). Typically, the aim is to offer a functional solution (the classic example is power-by-the-hour rather than selling an engine) that fulfills a unique customer need. Such offerings call for a greater focus on a co-creation approach, which redefines customer-supplier relationships. Therefore, providing integrated solutions has been described as an ongoing relational process of defining, meeting, and supporting a customer's evolving needs by establishing new roles in traditional value chains (Reim et al. 2018; Tuli et al. 2007). However, if transformations are managed well within the firm and at the network-partner level, companies can gain long-term competitiveness through increased customization, thereby avoiding product commoditization, securing stable revenues, and generating higher profit margins. 


\section{Digitalization (trend 3)}

Numerous industry reports highlight the influential role of digitalization and Industry 4.0 because they are expected to significantly improve competitiveness. There is no consensus regarding the definition of digitalization. A recent report by Gather digitalization defines digitalization as the use of digital technologies to change a business model and provide new revenue and value-producing opportunities. It thus represents the process of moving to a digital business. Through digitalization, companies can increase their ability to analyze data by connecting products and allowing products to collect data using sensors.

Given the potential of this technological revolution, digitalization is the cause of sweeping transformations in multiple business areas, providing unparalleled opportunities for value creation and capture while also representing a major source of risk (Porter and Heppelmann 2014). The literature describes how companies and managers across all sectors grapple with the strategic implications of these transformations for their organizations, their industry ecosystems, and society. The economic and social implications of digitalization are contested, and they raise serious questions about the wider impact of digital transformation (Brynjolfsson and McAfee 2012; Nylén and Holmström 2015).

Awareness of the consequences of digitalization is something companies need to acknowledge when trying to manage the influence of this trend (Porter and Heppelmann 2014). The pace of change in the digital age is unprecedented, and it represents new and uncalculated risks that companies must address for the first time. Security, privacy, and digital ethics must be integral parts of the development process from the outset and represent new security considerations. Responsibility in terms of consumer privacy and demands for the transparent use of data are common issues today. Organizations will benefit from using the Internet of things (IoT) or its applications to transform to a digital business. The IoT is a computing concept that refers to the idea of everyday physical objects being connected to the Internet and being able to identify themselves to other devices. According to Gartner, 8.8 billion devices are already connected to the IoT, and by 2020 , there will 20 billion connected devices. The IoT can be used for strategic asset management to monitor the status, location, and movement of physical assets owned by the organization to increase performance, efficiency, safety, security, and the throughput of individual assets and groups of assets. Moreover, IoT can be used to improve customer experience based on information about the customer, consumer, or employee collected via IoT devices. However, most companies are still unable to truly exploit the benefits of digitalization because of transformational needs.

Neglecting digitalization can have a major influence on company failure in various ways. According to IBM, companies that are skilled at using big data and analytics to innovate are $36 \%$ more likely to outperform peers in revenue growth and operating efficiency (IBM 2015). For example, efficiency can be increased by having accurate data on a machine's maintenance needs and being able to repair it before breakage. Non-digital companies face different issues that curb productivity. Examples include manual data entry, or systems that do not communicate to each other leading to manual data entry, and process bottlenecks due to a need to wait for one process to go through a single department, creating delays. But digitalization can eliminate many such 
bottlenecks by replacing legacy processes with automated workflows. Over the past few years, the amount of data has increased. Businesses need to access these large amounts of data and use them. However, not all companies can handle data in this way. Many lack the tools and processes needed to turn data into manageable information. A failure to digitalize will restrict companies from capitalizing on this data through modern business intelligence (BI) and artificial intelligence (AI) tools and will prevent them from reacting with speed and precision. Failure to act upon digitalization will also restrict companies' ability to make the business available to customers or potential customers anywhere. Thus, digitalization represents a truly influential trend that must be embraced by companies to ensure future competitiveness. Although digitalization may create initial challenges for individual entrepreneurs and companies upon being implemented (Malmström and Wincent 2018) this is a trend that will be a fundament in the future.

\section{Firm-level transformation toward sustainability}

\section{Business model innovation}

The above trends related to the circular economy, servitization, and digitalization call for radical changes in firms' business models to gain sustainability benefits. Business model innovation involves changes in a firm's cognitive schema and conceptual representation, which explains transitions in how companies create, deliver, and capture value through the exploitation of business opportunities (Zott and Amit 2010). The assumption is that digitalization, the circular economy, and servitization influence how managers must theorize and develop ideas and how current (and future) business models are viewed. This represents the foundation for business model innovation and, more importantly, firm-level transformation (Martins et al. 2015).

We argue that the connections between changes in how managers think, how to meet market demands, and how to act upon trends are the real facilitators of transformation. A business model describes how value will be created for new or existing customer segments as well as how that value will be delivered and captured through revenue models (Teece 2010). Specifically, the business model answers four key questions covering four dimensions (Frankenberger et al. 2013a). Therefore, managers and companies may need to reformulate what is offered to the customer, how activities and processes are employed to deliver the promised value, and what the revenue model looks like, as well as who the target customer is. Taking steps toward business model innovation can enable companies to maintain or regenerate new environmental, social, and economic capital beyond firm boundaries (Schaltegger et al. 2016). Firms cannot work in silos with these four dimensions because they are interdependent and must be aligned to maximize the true business model potential. Digitalization and circular economy influences as well as the need for servitization in many sectors point to the need to upgrade to sustainable business models.

New types of digital solutions, environmental concerns, and service perspectives on consumption require companies to adapt and organize new ways to profit when they solve large-scale complex problems (Frishammar et al. 2018). Research has highlighted several types of increasingly important business models. Among the areas of attention are new and innovative ways to reduce environmental effects by assuming life-cycle responsibility, improving operations, developing new product-services, and pursuing 
alternative ways to accomplish more effective consumption (Reim et al. 2015; Parida et al. 2014). These are all components that require substantial changes in the overall business model to adapt to the new environmental conditions. Even if the circular economy is not fully adjusted for, there is a consensus in the literature that the effectiveness of even well-designed business models is limited if a sustainable balance is not considered and adopted (Bocken et al. 2014; Boons and Lüdeke-Freund 2013; Lewandowski 2016; Reim et al. 2015; Schaltegger et al. 2016). The business model should therefore be designed to benefit from integrating sustainability components in contexts where this is increasingly changing the business landscape. Examples of such business models include the use of use-oriented and results-oriented models (Tukker 2004). A firm with a use-oriented business model makes a product available under rental or leasing agreements but retains ownership. The product is not sold to the customer, but its availability is guaranteed for a predefined period, during which the provider receives payment in installments. An example of this business model in the automotive industry is car2go or zipcar. In a results-oriented business model, the firm guarantees a customer a predefined result or outcome. The supplier gets paid for the result, for which it assumes full responsibility. For example, the mine-equipment provider Metso offers cost-per-ton agreements under which it is rewarded according to the output or performance of the customer.

The research on business model transformation has tended to study sustainable niche market pioneers rather than mass-market incumbents (Schaltegger et al. 2016). Moreover, much research on business model transformation toward the circular economy and sustainability is either conceptual or offers a static view of what is actually a complex and dynamic reality (Lewandowski 2016; Roome and Louche 2016). For example, studies have classified servitization business model characteristics by structure (Barquet et al. 2013) and have proposed sustainability-based versions of wellknown business model blueprints (Lewandowski 2016). In other words, most of the limited research on circular business models has focused on the business model per se rather than the process whereby firms actually transform their business models (Frankenberger et al. 2013a; Roome and Louche 2016). How firms go about developing or transforming their business models is thus poorly understood (Achtenhagen et al. 2013). Consequently, there is a need for new insights that support firms in their transition toward sustainability (Lewandowski 2016). Finally, a key shortcoming of the literature is the prevailing focus on a single firm's business model. Because business models transcend organizational boundaries (Chesbrough 2003), contributions by partners in the ecosystem must be better understood, especially in so-called outputbased business models (Frankenberger et al. 2013b; Windahl and Lakemond 2006). Although several avenues seem worthy of research, the literature has significant gaps in the following broad areas:

- Which industries are highly influenced by digitalization, the circular economy, and servitization trends and have the fastest rate of transfer to new business models? Changes in digitalization and technology are under-discussed in the recent academic literature. Although the circular economy and servitization are considered important, our knowledge of their impact is limited.

- Which industries and environments have the highest demands and most severe constraints to changing to a new business model? The contribution of a sustainable 
business model is likely to be different, and its implementation is likely to differ across industries. The blueprint is very limited if the industry is not structured such that the company, who provides the blueprint, has no opportunity to integrate surrounding partners to achieve overall improvements to better deploy its strategies.

- What type of business model is most profitable? How should the four elements of a business model be managed to maximize the benefits of the proposed trends? How should the elements of the business model be aligned to ensure that the revised business model delivers on promised benefits?

- To what extent can larger and established industrial companies transform their business models? Consistent with the notions of constrained strategic choice theory, many companies lack the abilities to engage in such change. Therefore, we expect many new constructs to be important for the study of the new trends toward sustainability or related major environmental changes.

- How can firms cope with organizational change in the business model transformation phase? How can firms ensure that the emerging business model does not cannibalize existing business models? Can two or more business models co-exist within a company?

- How can firms develop an ecosystem business model where multiple actors' interests are aligned to exploit opportunities triggered by digitalization, the circular economy, and servitization?

\section{Resources and capabilities}

Recent research has also shown that companies must use the trends of digitalization, the circular economy, and servitization by looking inward and developing capabilities to meet new demands (Parida et al. 2015; Lahti et al. 2018). According to the resourcebased view (Barney 1991; Wernerfelt 1984), capabilities are "complex bundles of skills and accumulated knowledge, exercised through organizational processes that enable firms to coordinate activities and make use of their assets" (Day 1994, p. 38). In the context of proposed trends and firm-level transformation, numerous capabilities can be of importance (Windahl and Lakemond 2010; Gebauer et al. 2013; Kindström et al. 2013), such as operational capabilities (Windahl and Lakemond 2010; Gebauer et al. 2013), dynamic capabilities (Kindström et al. 2013), strategic capabilities (Ulaga and Reinartz 2011), network capability (Kohtamäki et al. 2013; Sjödin et al. 2018), and service innovation capability (Parida et al. 2015).

The resource-based view (Barney 1991) provides a useful explanation of how to capitalize upon the trends of digitalization, the circular economy, and servitization and highlights the importance of meeting four basic conditions for new resource and capability upgrades. The first refers to improvements in following the trends of digitalization, the circular economy, and servitization and the exploration of such opportunities that come with the trends' ability to increase the value of a company's products and production. Second, the upgrades that the company achieves by exploring such opportunities or trends should be rare and not commonly offered by others in the market. The third condition is that the investments must be difficult to imitate. Although investments are often not as difficult to imitate as other production or market resources, investments in company-specific areas that may improve how the company differentiates 
itself from competitors in terms of digitalization, the circular economy, and servitization is important. Finally, the company's digitalization, circular economy, and servitization investments and upgrades should not be vulnerable to substitutes or replacements to provide an enduring and sustainable competitive advantage. Although some sustainable technology investments may not sustain the rapid and increasingly demanding shift toward environmental caution and the use of renewable resources and inputs, the already high demands of sustainability in industries may increasingly reduce the risk that at least some sustainability investments quickly become obsolete (Parida et al. 2015).

Studies have explored and acknowledged the trends highlighted in our framework, although in a highly fragmented way. A review of the literature shows that the development of new forms of sustainable capabilities is limited and such capabilities are rarely carefully implemented and aligned with strategy to ensure that companies capitalize on any potential sources of profitability. Implementation is often costly and may interfere with optimal ways to organize production, nor is it optimized with the execution of organizational strategy (Parida and Örtqvist 2015; Black and Boal 1994). Moreover, consistent with the notions of constrained strategic choice theory, many companies seem to lack the ability to engage in such change. We therefore expect many new constructs to prove important for the study of new trends in sustainability or related major environmental changes. Thus, we recognize that focusing on resources and capabilities is central to ensure successful firm-level transformation to benefit from the discussed trends and achieve sustainable benefits. However, the literature has numerous shortcomings, which must be address by researchers in the field. The following questions can be used to develop a future research agenda in this area:

- What factors determine the extent to which companies embrace the trends of digitalization, the circular economy, and servitization by aligning their strategy with new capabilities to address changes in the environment? Studies have examined the antecedents and consequences of sustainable innovation, although most studies have focused on the latter, and research in this area is scarce.

- Which trend is most accountable for driving the transition to new resources and capabilities? What is the role of top management? Research has shown that many transitions may be slow, may be initiated in response to policy requirements, and may be initiated and implemented through roles outside strategic influence and traditional top management teams.

- How fast should investments be made and what investments are needed? What is the relative importance of the new generation of capabilities to other company specific capabilities? A review of the literature shows that sustainable innovations are often underused because they are not carefully implemented or aligned with strategies. We also observe that this implementation is often costly and may interfere with optimal ways to organize production. Furthermore, it is not optimized with the execution of organizational strategy.

- How can it be ensured that interdependence and interplay between capabilities are understood strategically? Is it possible to expect companies' capabilities to have compensatory, enhancing, or suppressing effects on each other? If so, which configurations of capabilities are most influential at providing sustainability benefits? 
- How are new capabilities developed within existing organizations to capitalize on emerging trends? What are the micro-foundations of capability development for sustainability? What is the role of individuals and teams in capability development?

\section{Network-level transformation for sustainability}

\section{Co-creation with ecosystem partners}

To benefit from emerging trends associated with digitalization, the circular economy, and servitization, network-level transformations are needed. A key dimension relates to ensuring value co-creation with partners to maximize and jointly exploit sustainability benefits. According to a growing number of studies, companies increasingly need to assess their new roles and often need to redefine roles of partner companies to increase process output, improve performance, and/or achieve cost savings (Sjödin et al. 2016). In co-creation efforts, customer and provider roles are challenged when jointly working to select and integrate resources into solutions within operations. How such challenges affect customers' perceived value is of the utmost interest. Value co-creation is a harbinger for the next generation of value creation in companies when addressing and capitalizing on the trends of digitalization, the circular economy, and servitization. It is therefore important to understand that to be able to successfully offer integrated solutions, a key value facilitator is the customer as a co-creator of value (Lusch and Vargo 2008). In a recent paper, Grönroos and Voima (2013, p.141) further extended this view, explaining that "understanding the customers practices and how customers combine resources, processes, and outcome in interaction, the service provider shifts from a mere facilitator to a co-creator of value." This implies that during value creation, provider and customer operate in a joint sphere, where they both take an active role in value creation through direct interaction.

During value co-creation while following trends such as digitalization, the circular economy, and servitization, the responsibility for the outcome is shared between the customer and the provider as they work jointly to plan, implement, and monitor the solution (Brady et al. 2005). More specifically, the customer creates value, and the provider's integrated solutions facilitate customer value creation in direct interaction (Grönroos and Voima 2013; Tuli et al. 2007). For the provider to be active in co-creating value, however, requires willingness on the customers' part. Currently, we have limited knowledge about the activities and complexities associated with value co-creation in provider-customer relationships regarding integrated product-service solutions.

Customers might invite a provider to offer integrated solutions at different points of the production process, which can broaden the scope of the traditional relationship. Such extension, however, also creates relational complexities and possibilities for value destruction (Echeverri and Skålén 2011). According to Tuli et al. (2007), offering an integrated product-service solution under such contexts could require significant investment in relationship-building activities, including the investment of time and resources to understand customer problems and generate a better understanding of how customers use and operate a solution from sale to decommissioning (Davies 2004; Parida et al. 2014). This implies that the nature of the interactions between buyer and seller is more collaborative (i.e., from transaction-based to relationship-based interactions). 
Few studies have addressed the interactions between customers, suppliers, and other partners during value co-creation. Several authors, however, have outlined different process phases to describe the development and implementation of integrated productservice solutions (e.g., Aarikka-Stenroos and Jaakkola 2012; Davies et al. 2007; Rönnberg Sjödin 2013; Sawhney 2006; Storbacka 2011; Tuli et al. 2007). For example, Sawhney (2006) described the process of solution development in terms of phases such as analyzing a customer problem, defining customer outcomes, mapping customer activities, identifying products and services needed to solve the entire problem, and integrating (implementing) solutions. Similarly, Tuli et al. (2007) affirmed that a process-centric view of solutions comprises distinct phases such as definition of requirements, customization and integration, deployment, and post-deployment support. Building on these authors' work, we outline three overarching phases of the cocreation process: 1) requirement definition, 2) customization and integration, and 3) implementation and operation. Thus, we argue that co-creation with customers can be complex and needs specific attention during different phases of the relationship to ensure sustainability benefits.

- What are the activities that underline value co-creation between multiple partners? How does the co-creation process unfold between partners?

- What are the complexities associated with value co-creation? A number of authors have started to explore the linkages between networks, value co-creation, and competition. It is likely that value creation logic is changing.

- How can we define the new types of value co-creation? The literature often defines value creation as something that is not particularly well suited to the study of sustainability concerns. There is no clear definition of new types of partnerships; future studies should define such networks or partnerships.

- How does a company determine that the partner is suitable for value co-creation when responding to the new trends of digitalization, the circular economy, and servitization?

\section{Ecosystem orchestration}

Trends such as digitalization, the circular economy, and servitization and their associated new business models present a unique value creation opportunity. However, they also entail several challenges associated with greater risk and responsibility associated with significant changes in a firm's ecosystem. According to Reim et al. (2015) the mechanism for how companies are expected to create, deliver, and capture value must be overhauled. For example, companies must extend interactions and manage relationships with customers throughout the product life cycle. Moreover, the need for new types of capabilities and new types of business models requires consideration and reanalysis of the wider company ecosystem of how services are integrated to ensure sustainable benefits with the highest customer value (Lockett et al. 2011; Mont 2002). According to Grönroos and Voima (2013), such a change can be perceived as challenging because of the inability to develop business models that motivate companies to offer or acquire results-oriented product and service combinations (e.g., functional results-based services). This inability arises because companies 
are required to operate in a joint sphere. In this case, business model issues transcend the value chain relationships. They thus require alignment of interests and incentives across eco-system actors. According to Su et al. (2013), the circular economy is realized in practice through parallel ongoing activities at micro (single object) meso (symbiosis association) and macro (city, province, or state) levels within an industry context. Still, the literature falls short because most studies focus on the providers' perceptions and lack insights into how customers and other ecosystem actors can jointly co-create value.

Following prior research, we acknowledge that ecosystems are orchestrated by ecosystem leaders to create value in collaboration with a community of actors. We draw on Moore's (1993) research, viewing a business ecosystem as a loosely coupled business community. Accordingly, we propose that adopting the ecosystem perspective may help explain and understand the implementation of digitalization, the circular economy, and servitization. The literature acknowledges that ecosystem leaders orchestrate business activities to create a shared vision of what values should be created (Nambisan and Sawhney 2011). Orchestration is defined "a set of deliberate, purposeful actions" performed by the core firm (Dhanaraj and Parkhe 2006, p. 659). It is through orchestration that focal firms can provide business ecosystems with institutional stability (Thomas and Autio 2013). Orchestration therefore also includes enforcing rules of the game and ensuring that other actors play by the rules. Such activities include promoting transparency between actors to control the risks of moral hazard, imposing sanctions, or even excluding actors who do not adhere to the rules (Williamson and De Meyer 2012).

Although scholars have described ecosystems and the way they may be orchestrated, it is less clear how ecosystems change, especially when embracing the new trends of digitalization, the circular economy, and servitization. Instead, the focus is descriptive, mapping how individual relationships are present and with whom relationships are formed. Thus, although research largely explains the logics within ecosystems, the way they change to fit new macro-level logics such as the circular economy is poorly articulated. Clarity is needed to understand how such changes occur and which mechanisms are applied by ecosystem leaders to promote circular economy principles. Thus, further research is required to explore how firms orchestrate ecosystem changes by transforming toward circular ecosystem business models.

Certain authors have started to explore the linkages between networks, ecosystems, and competition in sustainability. Research has shown that changes in a company's ecosystem are likely to be radical if the company implements a more radical change such as acting upon new, rapid trends like digitalization and the circular economy (Frishammar and Parida 2018). Thus, the literature suggests that the ecosystem and the structures of inter-organizational networks are important for the development of competitive advantages. We suggest the following areas of attention:

- How should companies structure ecosystems? Recent research has shown that the types, forms, and structures of inter-organizational networks must be revised to capitalize on new trends and opportunities.

- What is the role of virtual cooperation? Given the recognized role of virtual collaboration and the formation of distant relationships using technology, the role 
and form of today's networks look significantly different today from those of networks in the mid-1990s. For example, the literature cites a greater need for openness and inclusion because extranet and collaboration with open and inclusive networks facilitate impressive innovation and technology development.

- What is the role of "closing" or "opening" networks? Even the conditions for traditional closed restricted exclusive network forms, which are often designed and tightly controlled by a focal firm, have changed. We know little about the implications of these changes.

- What is the role of governance? Overall, there is less possibility of governing networks. We need a deeper understanding of how to establish and organize networks. This can ensure that the actors involved can effectively join forces with clear intentions to collaborate in implementing sustainable solutions to create competitive advantages. By exploring new ways of organizing and innovative ways of managing challenges, we observe that innovative networks can be formed under both short- and long-term arrangements. They may involve not only individual firms but also communities or stakeholders.

\section{Conclusions}

Changes through digitalization, the circular economy, and servitization are scarcely discussed in the recent academic literature. However, these changes hold significant effects on how companies cooperate to reduce waste and facilitate sustainability and how they formulate business models and capabilities. As indicated above, in many cases, new ways of working and a new way of organizing are required. This call is often not initiated by a focal firm, but rather the environment. This requirement is reflected by changes in a company's surrounding inter-organizational network. Through a business model that accounts for the surrounding inter-organizational network and collaborating partners, companies can generate greater opportunities for improved service delivery, the distribution of risks, shared accountability, and profitability from sustainability. Inter-organizational networks and new types of ecosystems ensure a broader set of resources and increased capacity. Multiple organizations and institutions can join forces to provide different knowledge and skills and thereby meet complex challenges related to sustainability.

Moreover, we argue for a need for academic researchers from entrepreneurship and innovation to engage in dialogue related to how the emerging trends are providing opportunities for sustainability through firm-and-network level transformation.

\section{Introduction to the special issue}

This special issue focuses on new perspectives of firm- and network-level transformations for sustainability. It also shows that trends and changes in the world require specific attention to innovate and develop entrepreneurial solutions that have managerial implications and influence how to work with sustainability. The call for papers for this special issue received considerable attention. A common characteristic of all the papers accepted in this special issue is that they contribute to the dialogue about how 
emerging trends influence firm- and network-level transformations. These papers are also diverse in terms of their industry focus, methods, and theoretical perspectives. This diversity ensures comprehensive coverage of the relevant topics in the field. Figure 2 provides a map of the papers in relation to the special issue framework. Below we briefly summarize each of the accepted papers.

In Paper 1, Sang Yoon Shin investigates how a venture capital network affects exit performance by focusing on advantages linked to holding a network position (i.e., a network advantage). This network advantage is examined at the syndicate level based on data from 1137 venture capital syndicate investments. The data largely confirm the predicted effects. The findings show that a syndicate's network advantage and its diversity are critical determinants of exit performance in the venture capital industry.

In paper 2, Matti Muhos, Martti Saarela, Delbert Foit Jr., and Lada Rasochova study the effect of digitalization and role of specialist start-ups in health service delivery. They argue that start-ups challenge the traditional healthcare industry by introducing radical and sustainable innovations. Still, little is known about the critical early growth processes of newly established digital healthcare service businesses. Building on experience-based priorities of managers of California-based digital healthcare startups, the authors develop a framework of management priorities. They find that network management is a high priority in digital service start-ups that are focused on bringing radical innovations to this complex and hard-to-access market where fundraising is an integral part of success.

In paper 3, Pankaj C. Patel extends the contribution to the conceptualization of absorptive capacity. The study investigates the entrepreneur's absorptive capacity during the opportunity development phase. This exploratory study was based on a

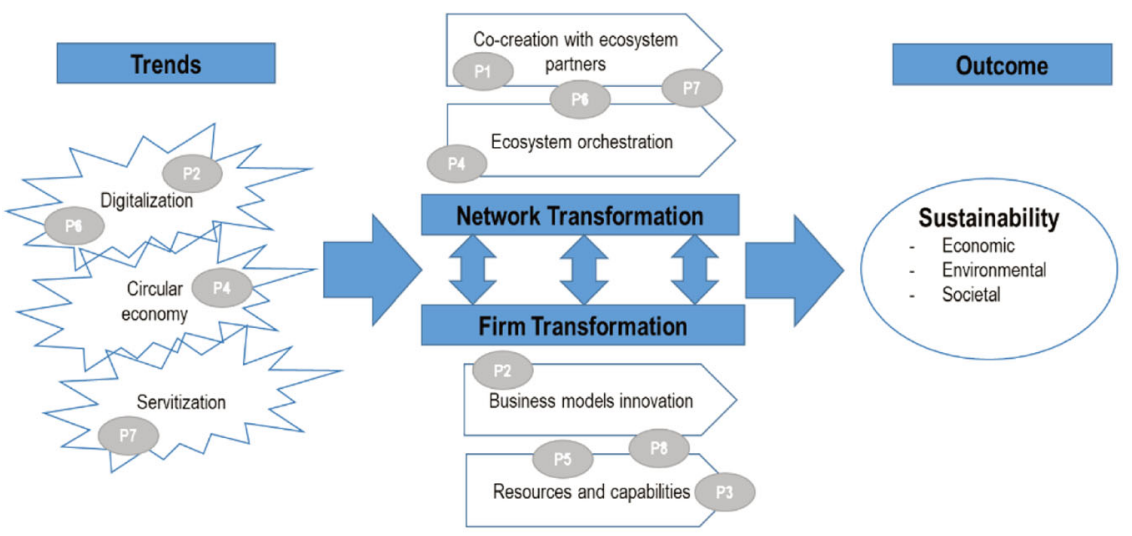

\begin{tabular}{|l|l|l|l|}
\hline Paper No & Author & Paper No & Author \\
\hline Paper 1 & Shin (2018) & Paper 5 & Gama (2018) \\
\hline Paper 2 & Matti et al (2018) & Paper 6 & Morgan et al (2018) \\
\hline Paper 3 & Patel (2018) & Paper 7 & Sjödin (2018) \\
\hline Paper 4 & Nordquist and Frishammar (2018) & Paper 8 & Heimonen and Kohtamäki (2018) \\
\hline
\end{tabular}

Fig. 2 Mapping special issue papers to the framework for emerging trends in transformation and sustainability outcomes 
sample of 93 Swedish entrepreneurs with at least one patent associated with their venture. The results indicate that entrepreneurial alertness is positively associated with opportunity-related absorptive capacity.

In paper 4, Sofia Nordqvist and Johan Frishammar explore how knowledge development and diffusion in demonstration plants support the development of sustainable technologies. Building on knowledge-based theory, they investigate four Swedish demonstration plants for advanced biofuels. The findings underscore the need for and production of domain-specific, procedural, and general knowledge to advance sustainable technology toward commercialization, with each type having a specific role and purpose.

In paper 5, Fábio Gama focuses on the collaborative ideation process and appropriability mechanisms (e.g., patents, copyright, legal agreements, document management, lead time, and secrecy) to protect knowledge spillover. The author argues that implementing suitable appropriability mechanisms during this collaborative ideation is a necessary yet difficult task. The study is based on exploratory case studies of three manufacturing firms. The results are communicated through a framework describing the managerial practices that influence the effectiveness of protection during the collaborative ideation process.

In paper 6, Todd Morgan, Sergey Alexander Anokhin, Chanho Song, and Natalya Chistyakova investigate how customer co-creation affects firms' ability to increase new product development (NPD) speed. Based on data from 204 SMEs, they find that firms that collaborate with customers in the NPD process at greater levels are able to increase NPD speed capabilities and commercialize products at a faster rate. Moreover, they report the moderating effect of customer participation on NPD speed.

In paper 7, David Sjödin investigates how firms can manage knowledge processing through co-creation in joint process innovation projects. Analysis of cross-comparative case studies, including nine industrial ecosystem actors, identifies three types of technological challenge (complexity, novelty, and customization) that create knowledgeprocessing requirements (uncertainty and equivocality) during the value co-creation process. This paper explains how three joint knowledge-processing strategies (joint problem solving, open communication, and end-user involvement) help ecosystem partners make sense of the requirements and demands in process innovation to manage these knowledge-processing requirements. The study contributes to the emerging literature on co-creation in process innovation by presenting a framework that describes the knowledge-processing dynamics in ecosystem relationships for process innovation.

In paper 8, Jesse Heimonen and Marko Kohtamäki propose the concept of new product and service portfolio (NPSP) advantage by creating and validating a three-dimensional measurement method that reflects novelty, meaningfulness, and superiority, which are the three characteristics of NPSP advantage. This study is based on data from 108 manufacturing companies. The study contributes to the new product development literature by indicating that these three characteristics of NPSP (i.e., novelty, meaningfulness, and superiority) are distinct characteristics that together constitute NPSP advantage.

Funding Information Open access funding provided by Hanken School of Economics.

Open Access This article is distributed under the terms of the Creative Commons Attribution 4.0 International License (http://creativecommons.org/licenses/by/4.0/), which permits unrestricted use, distribution, and reproduction in any medium, provided you give appropriate credit to the original author(s) and the source, provide a link to the Creative Commons license, and indicate if changes were made. 
Publisher's Note Springer Nature remains neutral with regard to jurisdictional claims in published maps and institutional affiliations.

\section{References}

Aarikka-Stenroos, L., \& Jaakkola, E. (2012). Value co-creation in knowledge intensive business services: A dyadic perspective on the joint problem solving process. Industrial Marketing Management, 41(1), 15-26.

Achtenhagen, L., Melin, L., \& Naldi, L. (2013). Dynamics of business models-strategizing, critical capabilities and activities for sustained value creation. Long Range Planning, 46(6), 427-442.

Baines, T., Lightfoot, H., Peppard, J., Johnson, M., Tiwari, A., Shehab, E., \& Swink, M. (2009). Towards an operations strategy for product-centric servitization. International Journal of Operations \& Production Management, 29(5), 494-519.

Barney, J. (1991). Firm resources and sustained competitive advantage. Journal of Management, 17(1), 99-120.

Barquet, A. P. B., de Oliveira, M. G., Amigo, C. R., Cunha, V. P., \& Rozenfeld, H. (2013). Employing the business model concept to support the adoption of product-service systems (PSS). Industrial Marketing Management, 42(5), 693-704.

Black, J. A., \& Boal, K. B. (1994). Strategic resources: Traits, configurations and paths to sustainable competitive advantage. Strategic Management Journal, 15(S2), 131-148.

Bocken, N. M., Short, S. W., Rana, P., \& Evans, S. (2014). A literature and practice review to develop sustainable business model archetypes. Journal of Cleaner Production, 65, 42-56.

Boons, F., \& Lüdeke-Freund, F. (2013). Business models for sustainable innovation: State-of-the-art and steps towards a research agenda. Journal of Cleaner Production, 45, 9-19.

Brady, T., Davies, A., \& Gann, D. M. (2005). Creating value by delivering integrated solutions. International Journal of Project Management, 23(5), 360-365.

Brynjolfsson, E., \& McAfee, A. (2012). Winning the race with ever-smarter machines. MIT Sloan Management Review, 53(2), 53.

Brynjolfsson, E., \& McAfee, A. (2014). The second machine age: Work, Progress, and prosperity in a time of brilliant technologies. New York: W. W. Norton \& Company.

Chesbrough, H. (2003). Open innovation: The new imperative for creating and profiting from technology. Boston: HBR Press.

Cohen, B., \& Winn, M. I. (2007). Market imperfections, opportunity and sustainable entrepreneurship. Journal of Business Venturing, 22, 29-49.

Davies, A. (2004). Moving base into high-value integrated solutions: A value stream approach. Industrial and Corporate Change, 13(5), 727-756.

Davies, A., Brady, T., \& Hobday, M. (2006). Charting a path toward integrated solutions. MIT Sloan Management Review, 47(3), 39-48.

Davies, A., Brady, T., \& Hobday, M. (2007). Organizing for solutions: Systems seller vs. systems integrator. Industrial Marketing Management, 36(2), 183-193.

Day, G. S. (1994). The capabilities of market-driven organizations. The Journal of Marketing, 58, 37-52.

Dean, T. J., \& McMullen, J. S. (2007). Toward a theory of sustainable entrepreneurship: Reducing environmental degradation through entrepreneurial action. Journal of Business Venturing, 22, 50-76.

Dhanaraj, C., \& Parkhe, A. (2006). Orchestrating innovation networks. Academy of Management Review, 31(3), 659-669.

Echeverri, P., \& Skålén, P. (2011). Co-creation and co-destruction: A practice-theory based study of interactive value formation. Marketing Theory, 11(3), 351-373.

Elkington, J. (1997). Cannibals with forks: The triple bottom line of 21st century business. Gabriola Island: New Society Publishers.

Frankenberger, K., Weiblen, T., Csik, M., \& Gassmann, O. (2013a). The 4I-framework of business model innovation: A structured view on process phases and challenges. International journal of Product Development, 18(3/4), 249-273.

Frankenberger, K., Weiblen, T., \& Gassmann, O. (2013b). Network configuration, customer centricity, and performance of open business models: A solution provider perspective. Industrial Marketing Management, 42(5), 671-682.

Frishammar, J., \& Parida, V. (2018). Circular business model transformation: A roadmap for incumbent firms. California Management Review. (forthcoming). 
Frishammar, J., Richtnér, A., Brattström, A., Magnusson, M., \& Björk, J. (2018). Opportunities and challenges in the new innovation landscape: Implications for innovation auditing and innovation management. European Management Journal. (forthcoming).

Gebauer, H., Fleisch, E., \& Friedli, T. (2005). Overcoming the service paradox in manufacturing companies. European Management Journal, 23(1), 14-26.

Gebauer, H., Paiola, M., \& Saccani, N. (2013). Characterizing service networks for moving from products to solutions. Industrial Marketing Management, 42(1), 31-46.

Grönroos, C., \& Voima, P. (2013). Critical service logic: Making sense of value creation and co-creation. Journal of the Academy of Marketing Science, 41(2), 133-150.

IBM. (2015). Innovative analytics (GBE03664-USEN-02). Somers, NY 10589.

Kibler, E., Wincent, J., Kautonen, T., Cacciotti, G., \& Obschonka, M. (2018). Can prosocial motivation harm entrepreneurs' subjective well-being?. Journal of Business Venturing. (Forthcoming).

Kindström, D., Kowalkowski, C., \& Sandberg, E. (2013). Enabling service innovation: A dynamic capabilities approach. Journal of Business Research, 66(8), 1063-1073.

Kohtamäki, M., Partanen, J., \& Möller, K. (2013). Making a profit with R\&D services-The critical role of relational capital. Industrial Marketing Management, 42(1), 71-81.

Kortmann, S., \& Piller, F. (2016). Open business models and closed-loop value chains: Redefining the firmconsumer relationship. California Management Review, 58(3), 88-108.

Lahti, T., Wincent, J., \& Parida, V. (2018). A definition and theoretical review of the circular economy, value creation, and sustainable business models: Where are we now and where should research move in the future? Sustainability, 10(8), 2799.

Lenka, S., Parida, V., \& Wincent, J. (2017). Digitalization capabilities as enablers of value co-creation in Servitizing firms. Psychology \& Marketing, 34(1), 92-100.

Lenka, S., Parida, V., Sjödin, D. R., \& Wincent, J. (2018a). Exploring the microfoundations of servitization: How individual actions overcome organizational resistance. Journal of Business Research, 88, 328-336.

Lenka, S., Parida, V., Sjödin, D. R., \& Wincent, J. (2018b). Towards a multi-level servitization framework: Conceptualizing ambivalence in manufacturing firms. International Journal of Operations \& Production Management, 38(3), 810-827.

Lewandowski, M. (2016). Designing the business models for circular economy-Towards the conceptual framework. Sustainability, 8(1), 43.

Lightfoot, H. W., \& Gebauer, H. (2011). Exploring the alignment between service strategy and service innovation. Journal of Service Management, 22(5), 664-683.

Lockett, H., Johnson, M., Evans, S., \& Bastl, M. (2011). Product service systems and supply network relationships: An exploratory case study. Journal of Manufacturing Technology Management, 22(3), 293-313.

Lusch, R. F., \& Vargo, S. L. (2008). The service-dominant mindset. In Service science, management and engineering education for the 21st century (pp. 89-96). Springer, Boston, MA.

MacArthur, E., Zumwinkel, K., \& Stuchtey, M. R. (2015). Growth within: A circular economy vision for a competitive Europe. Ellen MacArthur Foundation.

Malmström, M., \& Wincent, J. (2018). The Digitization of Banks Disproportionately Hurts Women Entrepreneurs. Harvard Business Review, September.

Martins, L. L., Rindova, V. P., \& Greenbaum, B. E. (2015). Unlocking the hidden value of concepts: A cognitive approach to business model innovation. Strategic Entrepreneurship Journal, 9(1), 99-117.

Meier, H., Roy, R., \& Seliger, G. (2010). Industrial product-service systems-IPS2. CIRP AnnalsManufacturing Technology, 59(2), 607-627.

Mont, O. K. (2002). Clarifying the concept of product-service system. Journal of Cleaner Production, 10(3), $237-245$.

Moore, J. F. (1993). Predators and prey: A new ecology of competition. Harvard Business Review, 71(3), 75-86.

Nambisan, S., \& Sawhney, M. (2011). Orchestration processes in network-centric innovation: Evidence from the field. Academy of Management Perspectives, 25(3), 40-57.

Normann, R. (2001). Reframing business - When the map changes the landscape. Chichester: Wiley.

Nußholz, J. (2017). Circular business models: Defining a concept and framing an emerging research field. Sustainability, 9(10), 1810.

Nylén, D., \& Holmström, J. (2015). Digital innovation strategy: A framework for diagnosing and improving digital product and service innovation. Business Horizons, 58(1), 57-67.

Parida, V., \& Örtqvist, D. (2015). Interactive effects of network capability, ICT capability, and financial slack on technology-based small firm innovation performance. Journal of Small Business Management, 53, 278-298.

Parida, V., Sjödin, D., Wincent, J., \& Kohtamäki, M. (2014). Mastering the transition to product-service provision: Insights into business models, learning activities, and capabilities. Research-Technology Management, 57(3), 44-52. 
Parida, V., Sjödin, D. R., Lenka, S., \& Wincent, J. (2015). Developing global service innovation capabilities: How global manufacturers address the challenges of market heterogeneity. Research-Technology Management, 58(5), 35-44.

Porter, M. E., \& Heppelmann, J. E. (2014). How smart, connected products are transforming competition. Harvard Business Review, 92(11), 64-88.

Reim, W., Parida, V., \& Örtqvist, D. (2015). Product-service systems (PSS) business models and tactics-a systematic literature review. Journal of Cleaner Production, 97, 61-75.

Reim, W., Parida, V., \& Sjödin, D. R. (2016). Risk management for product-service system operation. International Journal of Operations \& Production Management, 36(6), 665-686.

Reim, W., Sjödin, D., \& Parida, V. (2018). Mitigating adverse customer behaviour for product-service system provision: An agency theory perspective. Industrial Marketing Management., 74, 150-161.

Roome, N., \& Louche, C. (2016). Journeying toward business models for sustainability: A conceptual model found inside the Black box of Organisational transformation. Organization \& Environment, 29(1), 11-35.

Sawhney, M. (2006). Going beyond the product. The service-dominant logic of marketing: Dialogue, debate, and directions, 15, 365-380.

Schaltegger, S. (2002). A framework for ecopreneurship. Leading bioneers and environmental managers to ecopreneurship. Greener. Management International, 38, 45-58.

Schaltegger, S., Hansen, E. G., \& Lüdeke-Freund, F. (2016). Business models for sustainability: Origins, present research, and future avenues. Organization \& Environment, 29(1), 3-10.

Sjödin, D. R. (2013). A lifecycle perspective on buyer-supplier collaboration in process development projects. Journal of Manufacturing Technology Management, 24(2), 235-256.

Sjödin, D. R., Parida, V., \& Wincent, J. (2016). Value co-creation process of integrated product-services: Effect of role ambiguities and relational coping strategies. Industrial Marketing Management, 56, 108-119.

Sjödin, D. R., Parida, V., Leksell, M., \& Petrovic, A. (2018). Smart factory implementation and process innovation. Research-Technology Management, 61(5), 22-31.

Storbacka, K. (2011). A solution business model: Capabilities and management practices for integrated solutions. Industrial Marketing Management, 40(5), 699-711.

Storbacka, K., Windahl, C., Nenonen, S., \& Salonen, A. (2013). Solution business models: Transformation along four continua. Industrial Marketing Management, 42(5), 705-716.

Su, B., Heshmati, A., Geng, Y., \& Yu, X. (2013). A review of the circular economy in China: Moving from rhetoric to implementation. Journal of Cleaner Production, 42, 215-227.

Teece, D. J. (2010). Business models, business strategy and innovation. Long Range Planning, 43(2-3), 172-194.

Thomas, L., \& Autio, E. (2013). Emergent equifinality: an empirical analysis of ecosystem creation processes. In Proceedings of the 35th DRUID Celebration Conference, Barcelona, Spain (Vol. 80).

Tukker, A. (2004). Eight types of product-service system: Eight ways to sustainability? Experiences from SusProNet. Business Strategy and the Environment, 13(4), 246-260.

Tukker, A. (2014). Rare earth elements supply restrictions: Market failures, not scarcity, hamper their current use in high-tech applications. Environmental Science and Technology, 48(17), 9973-9974.

Tukker, A. (2015). Product services for a resource-efficient and circular economy-a review. Journal of Cleaner Production, 97, 76-91.

Tuli, K. R., Kohli, A. K., \& Bharadwaj, S. G. (2007). Rethinking customer solutions: From product bundles to relational processes. Journal of Marketing, 71(3), 1-17.

Ulaga, W., \& Reinartz, W. J. (2011). Hybrid offerings: How manufacturing firms combine goods and services successfully. Journal of Marketing, 75(6), 5-23.

Upward, A., \& Jones, P. (2016). An ontology for strongly sustainable business models: Defining an enterprise framework compatible with natural and social science. Organization \& Environment, 29(1), 97-123.

Vandermerwe, S., \& Rada, J. (1988). Servitization of business: Adding value by adding services. European Management Journal, 6(4), 314-324.

Vargo, S. L., \& Lusch, R. F. (2008). Service-dominant logic: Continuing the evolution. Journal of the Academy of Marketing Science, 36(1), 1-10.

Wernerfelt, B. (1984). A resource-based view of the firm. Strategic Management Journal, 5(2), 171-180.

Williamson, P. J., \& De Meyer, A. (2012). Ecosystem advantage: How to successfully harness the power of partners. California Management Review, 55(1), $24-46$.

Windahl, C., \& Lakemond, N. (2006). Developing integrated solutions: The importance of relationships within the network. Industrial Marketing Management, 35(7), 806-818.

Windahl, C., \& Lakemond, N. (2010). Integrated solutions from a service-centered perspective: Applicability and limitations in the capital goods industry. Industrial Marketing Management, 39(8), 1278-1290.

Zott, C., \& Amit, R. (2010). Designing your future business model: An activity system perspective. Long Range Planning, 43, 216-226. 